\title{
Experimental Study on the Influence of Zirconia Surface Preparation on Deposition of Hydroxyapatite
}

\author{
SERGIU CIPRIAN FOCSANEANU1,2, PETRICA VIZUREANU ${ }^{1,3 *}$, ANDREI VICTOR SANDU ${ }^{1,4}$, GABRIELA CIOBANU4, \\ SIMONA MADALINA BALTATU', DANIELA VLAD ${ }^{5}$ \\ ${ }^{1}$ Gheorghe Asachi Technical University of lasi, Faculty of Materials Science and Engineering, 41 D. Mangeron Str., 700050, Iasi, \\ Romania \\ ${ }^{2}$ Centre of Excellence Geopolymer and Green Technology (CeGeoGTech), Universiti Malaysia Perlis, Malaysia \\ ${ }^{3}$ Romanian Inventors Forum, 3 Sf. P. Movila, 700089, Iasi, Romania \\ ${ }^{4}$ Gheorghe Asachi Technical University of lasi, Faculty of Chemical Engineering and Environmental Protection, D. Mangeron Str., \\ 700050, Iasi, Romania \\ ${ }^{5}$ Grigore T.Popa University of Medicine and Pharmacy, Faculty of Medical Bioengineering, 9 M. Kogalniceanu Str., 700454, Iasi, \\ Romania
}

\begin{abstract}
The present article is a preliminary study focused on the influence of zirconia surface on deposition of hydroxyapatite. The surface characteristics are very important for deposition of various materials. Most of the studies on zirconia are focused on dopped ZrO, composites or on surface enhancement of these kind of materials. One of the most important property is the osseointegration which can be enhanced with various kind of treatments or deposition. Our preliminary study involved the mechanical grinding and respectively the chemical attack of the surface before the deposition. The results highlights that in order to obtained a better layer of hydroxyapatite the surface of the zirconia samples need to be prepared by chemical attack.
\end{abstract}

Keywords: zirconia, surface, hydroxyapatite, osseointegration

At global level there is a high concern for the research and development of materials for medical and biomedical applications. The main areas of biomaterial applications are: orthopedics, cardiovascular surgery, ophthalmology, dentistry, urology, aesthetic surgery, neurology, suture materials for wound healing, controlled release drug delivery systems [1-5].

Biomaterials play an important role not only in the diagnosis and treatment of a disease, but also in its subsequent evolution, because on contact with living matter, the reciprocal biomaterial-organism reaction can be beneficial or harmful [3-8].

The first introduced in dentistry was ceramics with in the form of coatings onto metal-based endosseous implants. Zirconia is a material that recently appeared and revolutionized dentistry due to its physico-chemical characteristics and biological behavior towards superior tissue structures compared to all other metallic and nonmetallic materials that have been experimented and used in the field of implantology [1-5].

In lastdecade, hydroxyapatite (HAp), and zirconium was used as implant materials but only recently has been achieved composite materials ( $\left.\mathrm{HAp}-\mathrm{ZrO}_{2}\right)$ which combines the properties of the two components. Hydroxyapatite exhibits increased biocompatibility and osteoconductivity increased to strong tissues, such as bones and teeth, and has been used successfully as replacements or fillings for such tissues. Pure HAp is a white substance, natural apatites can have different shades of brown, yellow or green. HAp may also be used as a coating for metallic prostheses. However, hydroxyapatite exhibits mechanical strength and lower tenacity than bones, so HAp applications as bioceramic are somewhat limited. To improve the mechanical properties of $\mathrm{HAp}$, it was combined with $\mathrm{ZrO}$. Zirconia (zirconium dioxide - $\mathrm{ZrO}_{2}$ ) has biocompatibility and has high mechanical strength and has been used in orthopedics such as knee and hip joints [9-16].
Although the bone mineral part is almost identical to synthetic hydroxyapatite, there are some differences that occur both at the biological and mechanical levels.

In the following table we compare the mechanical properties of natural bone, synthetic hydroxyapatite and zirconia.

Table 1

MECHANICAL PROPERTIES OF BONE, HA AND ZIRCONIA

\begin{tabular}{|c|c|c|}
\hline & Compressive Strength & Elasticity modulus \\
\cline { 2 - 3 } & $(\mathrm{MPa})$ & $(\mathrm{GPa})$ \\
\hline Natural bone & $90-230$ & $3.8-17$ \\
\hline Sinthetic HA & $500-900$ & $35-120$ \\
\hline Zirconia & $>2000$ & $190-210$ \\
\hline
\end{tabular}

The work went from recent bibliographic studies on Zirconia alloys, being the starting point for improving a hydroxyapatite deposition on zirconia material to improve osseointegration, for restorative dentistry in general and oral implantology.

\section{Experimental part \\ Materials and methods}

The surface preparation of the ceramic samples is very important for the uniformity and adherence of the hydroxyapatite layer.

The studied zirconia is a commercial one used by dental shops. The samples were prepared as blocks. The surfaces used for deposition were prepared by mechanical grinding (up to a grit of 500) and respectively chemical attack (sulphuric acid solution).

The layers were deposited by biomimetic deposition technique. In order to obtain the deposition of thin crystalline hydroxyapapatite layers by biomimetic method we used a solution based on high concentration ions in calcium and phoshates (Simulated Body Fluid - SBF). The SBF solution 


\begin{tabular}{|l|c|c|c|c|c|c|c|c|}
\hline \multicolumn{1}{|c|}{ Ion } & $\mathrm{Na}^{+}$ & $\mathrm{Ca}^{2+}$ & $\mathbf{M g}^{2+}$ & $\mathrm{K}^{+}$ & $\mathrm{Cl}$ & $\left(\mathrm{HPO}_{4}\right)^{2-}$ & $\left(\mathrm{SO}_{4}\right)^{2-}$ & $\left(\mathrm{HCO}_{3}\right)^{-}$ \\
\hline SBF & 142.0 & 2.5 & 1.5 & 5.0 & 147.8 & 1.0 & 0.5 & 4.2 \\
\hline Blood plasma & 142.0 & 2.5 & 1.5 & 5.0 & 103.0 & 1.0 & 0.5 & 27.0 \\
\hline
\end{tabular}

Table 2

IONIC CONCENTRATION

FROM SBF And Blood

Plasma [Mmol/L]

is obtained by dissolving in demineralised water of the following substances: $\mathrm{NaCl}, \mathrm{NaHCO}_{3}, \mathrm{KCl}, \mathrm{Na}_{2} \mathrm{HPO}_{4}$ $\mathrm{MgCl}_{2} \cdot 6 \mathrm{H}_{2} \mathrm{O}, \mathrm{CaCl}_{2} 2 \mathrm{H}_{2} \mathrm{O}, \mathrm{Na}_{2} \mathrm{SO}_{4^{\prime}} \mathrm{HCl}$ and $\left(\mathrm{CH}_{2} \mathrm{OH}\right)_{3}^{2} \mathrm{CNH}_{2}$.

The ionic concentrations from the SBF solution compared with blood plasma are presented in table 2.

For surface characterization a SEM Tescan Vega II LSH was used, being coupled with a Bruker EDX for the evaluation of composition.

\section{Results and discussions}

The performance of the material in oral implantology today requires the review and assessment of the means that essentially contribute to ensuring the implant's stability and durability, starting from the nature of the biomaterial and continuing with the characteristics of the optimally designed sample.

The formation and deposition of the hydroxyapatite layer on the surface of immersed solids in the SBF biomimetic solution involves the production of chemical reactions in the biomimetic environment, the most important being the conversion of hydrogen phosphate into phosphate and hydrons. Only then is $\mathrm{HA}$ precipitated.

Our preliminary results highlights that in order to obtained a better layer of hydroxyapatite the surface of the zirconia samples need to be prepared by chemical attack, as it can be observed in figure 1 .
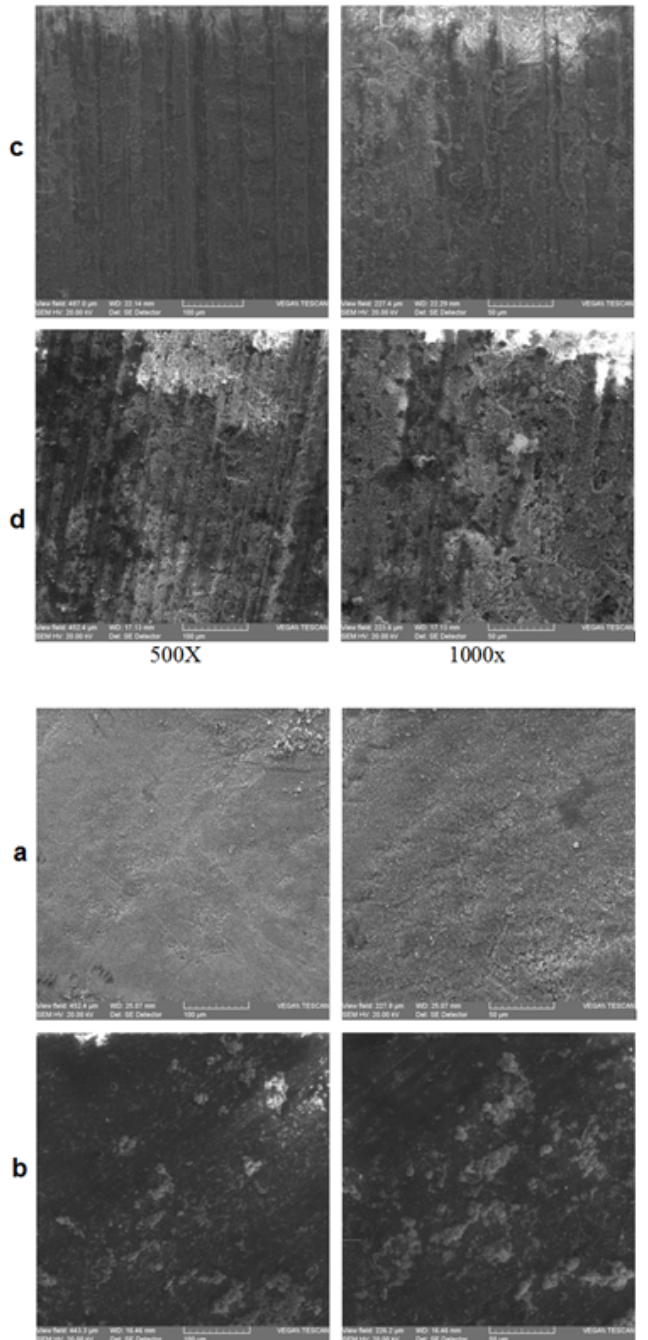

Fig. 1. The SEM Images at 500 and 1000 magnification: a -support surface, $b$-deposited surface without preparation, c - mechanical grinded surface, and $d$ - chemical attacked surface
Unlike other calcium phosphate compounds, $\mathrm{HA}$ is very stable under physiological conditions and is thermodynamically stable at physiological pH with an active role in bone remodelling by forming strong chemical bonds with the surrounding bone.

Although initially this implanted material has lower mechanical properties than the bone, it has been demonstrated in an in vivo experiment for 6 months that after this period due to the bindings produced, the mechanical strength may be superior to that of the patient's bone $[17,18]$.

In table 3 is presented the elemental composition determined by EDX of the sample surfaces.

Table 3

THE ELEMENTAL COMPOSITION ON THE SURFACE OF THE SAMPLES

\begin{tabular}{|c|c|c|c|}
\hline $\begin{array}{c}\text { Weight } \\
\%\end{array}$ & No & Mechanical & Chemical \\
\hline Zirconium & 59.54 & 52.66 & 32.61 \\
\hline Phosphorus & 9.35 & 8.15 & 12.63 \\
\hline Calcium & 1.42 & 1.63 & 2.27 \\
\hline Oxygen & 29.69 & 37.56 & 52.58 \\
\hline & 100 & 100 & 100 \\
\hline
\end{tabular}

From the images and the composition it is obvious that the chemical attack with sulphuric acid influences the deposition of the hydroxyapatite on the sample, having a more rough surface.

\section{Conclusions}

The deposition of the hydroxyapatite on zirconia can enhance the osseointegration of the material when used for dental or similar applications. The study provides a step forward for the better use of zirconia implants.

From the scanning electron microscopyimages coupled with EDX analysis resulted clearly a better deposition of the layer on the samples prepare on surface with a chemical attack.

\section{References}

1.OSMAN, R., SWAIN, M., Materials, 8, 2015, p. 932.

2.KOUTAYAS, S.O., VAGKOPOULOU, T., PELEKANOS, S., KOIDIS, P., STRUB, J.R.., Eur J Esthet Dent, 4, 2009, p. 348.

3.SCARANO, A., DI CARLO, F., QUARANTA, M., PIATTELLI, A., J. Oral Implantol. 29, 2003, p. 8.

4.TSUTSUMI, Y, NISHIMURA, D, DOI, H, NOMURA, N, HANAWA, T, Acta Biomaterialia 6, 2010, p. 4161

5.KANTANA, W., JARUPOOM, P., PENGPAT, K., EITSSAYEAM, S., TUNKASIRI, T., RUJ IJANAGUL, G., Ceramics International 39, 2013, p. S379.

6.BALTATU, M.S. VIZUREANU, P, TIEREAN, M.H. MINCIUNA, M.G., ACHITEl, D.C., Advanced Materials Research, 1128, 2015, p. 105. 7.BALTATU, M.S., VIZUREANU, P., MARECI, D., BURTAN, L.C., CHIRUTA, C., TRINCA, L.C., Materials and Corrosion-Werkstoffe und Korrosion, 67, no. 12, 2016, p. 1314.

8.BALTATU, M.S., VIZUREANU, P., CIMPOESU, R., ABDULLAH, M.M.A.B, SANDU, A.V., Rev. Chim. (Bucharest), 67, 2016, p. 2100.

9.BALTATU, M.S., TUGUI, C.A., PERJU, M.C., BENCHEA, M., SPATARU, M.C., SANDU, A.V., VIZUREANU, P., Rev. Chim. (Bucharest), 70, no. 4, 2019, p. 1302. 
10.MINCIUNA, M.G., VIZUREANU, P., ACHITEI, D.C., GHIBAN, N., SANDU, A.V., FORNA, N.C., Rev. Chim. (Bucharest), 65, 2014, p. 335. 11.SAVIN, A., STEIGMANN, R., IFTIMIE, N., NOVY, F., VIZUREANU, P., CRAUS, M.L., FINTOVA, S., IOP Conference Series: Materials Science and Engineering, 147, 2016, art. 012030.

12.ISTRATE, B., MUNTEANU C., MATEI, M.N., OPRISAN, B., CHICET, D., EARAR, K., IOP Conference Series: Materials Science and Engineering, 133, 2016, art. 012010.

13.ACHITEI, D.C., ABDULLAH, M.M.A., SANDU, A.V., VIZUREANU, P., Key Engineering Materials, 594-595, 2014, p. 133
14.MINCIUNA, M.G., VIZUREANU, P., GEANTA, V., VOICULESCU, I., SANDU, A.V., ACHITEI, D.C., VITALARIU, A.M., Rev. Chim. (Bucharest), 66, 2015, p. 891

15.WONG, M., EULENBERGER, J., SEHENK, R., HUNZIKER, E., J. Biomed. Mater. Res. 29, 1995, p. 1567.

16.GUAZZATO, M, ALBAKRY, M., RINGER, S.P., SWAIN, M.V., Dent. Mater, 20, 2004, p. 449.

17.LEGEROS, R.Z. LEGEROS, J.P., Key Eng. Mater., 240-242, 2003, p. 3. 18.FLEMING, J.E.JR., CORNELL, C.N., MUSCHLER, G.F., Ortho. Clin. North Am. 31, 2000, p. 357.

Manuscript received: 31.01 .2019 